\title{
FAKTOR PENGHAMBAT PENANGANANAN AKDIDIK PEMASYARAKATAN OLEH KONSELOR DI LEMBAGA PEMBINAAN KHUSUS ANAK
}

\author{
RUSFANDI \\ Dosen Fakultas Hukum Universitas Wiraraja Sumenep \\ rusfandi@gmail.com
}

\begin{abstract}
ABSTRAK
Petugas LPKAadalah seseorang pembina di LPKA yang berperan dalam proses pembinaan dengan tanggung jawab pengawasan, keamanan, dan keselamatan anak didik untuk meningkatkan dan mengembangkan sikap dan pengetahuan anakdidik secara terarah dan teratur guna menjadikannya orang baik dan berguna agar mampu utuk hidup bermasyarakat. Pembinaan Anak Didik Pemasyarakatan di LPKA ini tidak selalu berjalan mulus sesuai dengan tujuannya. Seperti di LAPAS bagi orang dewasa, tidak sedikit kasus Napi yang melakukan upaya pelarian. Seperti kasus bahwa dua anak didik LPKA melarikan diri dari LPKA. Keduaanak didik Lapas ini melarikan diri melalui atap yang sudah rapuh. Tidak hanya sekali itu sebelum sebelumnya juga pernah tejadi kasus pelarian di LPKA. Dengan adanya hambatan semacam ini proses penegakan hukum pidana khsusunya dalam tahap pembinaan menjadi terhalang. Maka perlu upaya penanganan yang harus dilakukan supaya proses penegakan hukum pidana khususnya tahapeksekusi/ pembinaan di LPKA dapat berjalan dengan baik.
\end{abstract}

Kata Kunci : Lembaga Pembinaan Khusus Anak.

\section{A. PENDAHULUAN}

Sistem hukum acara pidana merupakan rentetan tahapan penegakan hukum pidana mulai dari penyelidikan, penyidikan, penuntutan, persidangan, sampai pada eksekusi.Dari hasil putusan ini isinya dapat berupa pemidanaan terhadapseseorang yang telah melakukan tindak pidana dansanksi pidana ini dapat berupa penjara.Tempat eksekusi putusan pengadilan yang memutuskan pidana penjara terhadap seseorang yang melakukan tindak pidana adalah Lembaga Pemasyarakatan yang merupakan tempat pembinaan Narapidana dan Anak yang dijatuhi pidana selama menjalani hukuman agar mereka dapat menjadi manusia seutuhnya, menyadari kesalahan, memperbaiki dan tidak mengulangi kesalahan, sehingga mereka dapat menjalani kehidupan yang normal dan ikut serta melakukan pembangunan sebagaimana warga negara lainnya.

Lembaga Pemasyarakatan atau disingkat LAPAS ini merupakan salah satu perwujudan daripada tujuan hukum pidana. Seperti pendapat dari Muladi, tujuan dari hukum pidana hakikatnya adalah melindungi serta menjaga keseimbangan antara kepentingan negara dan masyarakat, kepentingan pelaku tindak pidana dan korban dari tindak pidana. Maka perlu suatu pemidanaan untuk menjaga keseimbangan kepentingan tersebut. Dalam ilmu hukum pidana ada 3 teori tentang tujuan pidana yakni teori pembalasan, teori relatif atau tujuan, dan teori gabungan. Teori pembalasan ini bermaksud bahwa tujuan dari 
pidana atau pemidanaan ini adalah sebagai pembalasan kepada orang yang telah melakukan perbuatan yang merugikan orang lain atau tindak pidana. Teori relatif atau tujuan bermaksud bahwa pemberian pidana ini bertujuan untuk memberi efek jera serta mencegah pengulangan tindak pidanabaik dari pelaku maupun dari orang lain. Sedangkan teori gabungan ini adalah teori pembalassan dan teori relatif yang digabungkan. Jadi tujuan pemidanaan adalah pembalasan sekaligus pemberian efek jera dan pencegahan serta untuk memperbaiki mental pelaku tindak pidana itu.

Sesuai dengan pengertian lapas di atas, LAPAS ini tidak hanya ditujukan bagi orang dewasa yang terbukti melakukan tindak pidana saja, namun juga ditujukan bagi anakanak yang juga melakukan tindak pidana. LAPAS orang dewasa dan anak pun berbeda, untuk LAPAS anak biasanya disebut dengan Lembaga PembinaanKhusus Anak atau disingkat LPKA, dan ketentuannya juga berbeda karena peraturan tentang anak sendiri pun berbeda dengan orang dewasa.Di Indonesia ada sistem peradilan pidana yang khusus diperuntukkan bagi anak yang melakukan tindak pidana mulaidari penyelidikan, penyidikan, penuntutan, pengadilan sampai dengan eksekusi. Sistem peradilan bagi anak ini telah diatur dalam Undang-Undang No. 11 Tahun 2012 tentang Sistem PeradilanPidanaAnak. Bagi anak yang telah terbukti melakukan suatu tindak pidana maka akan dikenakan beberapa sanksi.
Pembinaan di dalam lembaga dan pidana penjaramerupakan 2 bentuk sanksi pidana yang dilakukan dalam LPKA.

Pada dasarnya semua aktifitas yang dilakukan dalam rangka peradilan anak khususnya pidana penjara oleh LPKA harus didasarkan pada prinsip demi kesejahteraan anak dan kepentingan anak, mengingat dampak psikologis yang diterima oleh anak akibat tekanan dan stigmatisasi dari proses pemidanaan itu sendiri. Mengingat pada Pasal 28Bayat (2) UUD RI tahun 1945menyatakan bahwa "setiap anak berhak atas kelangsungan hidup, tumbuh dan berkembang serta berhak atas perlindungan darikekerasan dan diskriminasi."Maka dibutuhkan peradilan restoratif sebagai bentuk penanggulangan dari kasustindak pidana anak yang lebih memperhatikan kebutuhan khusus anak, serta untuk mengupayakan keadilan restoratif (restorative justice).

Peran LPKA menjadi sangatlah penting dalam proses pembinaan anak didik pemasyarakatan. Oleh sebab itu LPKAmenjaga keamanan dan ketertiban sehingga tujuan dari LAPAS ini bisa terlaksana.Maka tanggung jawab atas Anak Didik Pemasyarakatannantinya akanberalih dari Jaksa ke Lembaga Pemasyarakatan karena jaksa telah melimpahkannya ke Lembaga Pemasyarakatan.

LPKA (Lembaga PembinaanKhusus Anak)merupakan lembaga khususpembinaan bagi anak yang telah terbukti melakukan tindak pidana atau perbuatan yang dilarang 
oleh peraturan perundang-undangan dan norma hukum yang hidup dalam masyarakat yang diputuskan oleh putusan pengadilan. Anak yang menghuni LPKA ini dalam undang-undang disebut sebagai anak didik pemasyarakatan.

Berdasarkan Pasal 1 angka 8 UU No. 12 Tahun 1995 tentang Pemasyarakatan anak didik pemasyarakatan dibedakan menjadi 3 jenis, yakni anak pidana, anak negara dan anak sipil. Anak pidana ini merupakan anak yangberdasarkan putusan pengadilan menjalani pidana di LPKA paling lama sampai berumur 18 (delapan belas) tahun, anak negara adalah anak yang berdasarkan putusan pengadilan diserahkan kepada negara untuk dididik dan ditempatkan di LPKA paling lama sampai berumur 18 (delapan belas) tahun, sedangkan anak sipil ialah anak yang atas permintaan orang tua atau memperoleh penetapan pengadilan untuk dididik di LPKA paling lam sampai berumur 18 (delapan belas) tahun.

Dalam pembinaannyaada beberapa faktor menyangkut anak didik pemasyarakatan. Faktor ini meliputi jenis perkara, jenis pidana, lamanya masa pidana, jenis kelamin, usia, agama, suku bangsa, kondisi fisik dan psikologi, latar belakang pribadi anak, dan bakat serta hobi anak. Hal ini nantinya dijadikan sebagai acuan petugas dalam menerapkan sistem pendekatan dalam memberikan pembinaan bagi anak didik pemasyarakatan.
Pembinaan ini tidaklahselalu berjalan sesuai dengan tujuan. Ada beberapa hambatan-hambatan yang timbul dalam pembinaan. Salah satunya adalah anakdidik pemasyarakatan yang melarikan diridari LPKA. Jika hal ini terjadi maka menjadi kewajiban untuk segera menangani hambatan ini. Maka diperlukan upaya-upaya agar anakdidik pemasyarakatan yang lariini dapat kembali ke LPKA. Namun dalam peraturan perundang-undangan belum ada aturan yang mengatur secara teknis bagaimana saja upaya yang dapat dilakukan, maka petugas yang berkewajiban harus mempunyai inisiatif sendiri untuk mengembalikan anak didik ini kembali. tidak berhenti sampai disitu, jika anak didik sudah dikembalikan, ada upaya atau tindakan lagi yang dilakukan sebagai upaya penanganan hambatan ini, yakni hukuman disiplin. Penjelasan hukuman disiplin ini dijelaskan dalam Peraturan Menteri Hukum dan HAM RI No. 6 Tahun 2013 tentang Tata Tertib Lembaga Pemasyarakatan dan Rumah Tahanan Negara. Namun dalam Peraturan Menteri ini tidak membedakan jenis hukuman disiplin bagi narapidana dewasa dengan anak didik pemasyarakatan, dengan ini perlu kajian bahwa apakah pemberian hukuman disiplin ini sudah pantas atau sesuai bagi anak didik pemasyarakatan atau belum. 


\section{B. PEMBAHASAN}

Peranan konselor menurut Rogers adalah fasilitator dan reflektor. Disebut fasilitator karena konselor memfasilitasi atau mengakomodasi konseli mencapai pemahaman diri. Disebut reflektor karena konselor mengklarifikasi dan memantulkan kembali kepada klien perasaan dan sikap yang diekspresikannya terhadap konselor sebagai representasi orang lain. Dalam melaksanakan pembinaan, petugas (konselor)sebagai fasilitatortetap memperhatikan hak anak untuk memperoleh pelayanan, perawatan, pendidikan, pembimbingan, dan pendampingan serta hak lain sesuai dengan peraturan perundang-undangan.

Pembinaan anak harus berorientasi pada nilai kemanusiaan harus sesuai dengan perlindungan anak pidana. Pembinaan anak pidana harus memiliki program yang memanusiakan anak, mengasuh, membina, dan membimbing anak pidana.Petugas (konselor) memiliki tanggung jawab dalam proses pembinaan seperti mendorong untuk mengembangkan potensi anak didik, mencapai kehidupan berdaya guna untuk keluarga, masyarakat dan bangsanya, meningkatkan keimanan dan ketaqwaan sehingga menjadi manusia yang seimbang antara pengembangan intelektual, sosialemosional, dan moral religius. Pengembangan potensi intelektual menunjang tumbuhnya kreativitas dan produktivitas. Perkembangan sosial berorientasi kepada pengembangan relationship with other, yaitu agar mampu menjalin hubungan yang harmonis dengan orang lain di keluarga, sekolah, tempat pekerjaan, dan masyarakat. Sedangkan perkembangan emosional bertujuan agar terbentuk emosi yang stabil, dan sikap mental yang positif terhadap diri sendiri dan dunia luar.

Upaya pelaksanaan pembinaan anak pidana yang bertujuan untuk memperbaiki, menimbulkan rasa tobat berdasarkan keinsafan atau kesadaran dan sekaligus melindungi kepentingan masyarakat, yang berdasarkan Pancasila, prinsip pemasyarakatan dan nilai-nilai kemanusiaan. Petugas (konselor) dalam melaksanakan pembinaannya tidak berarti mengubah strukturmasyarakat yang sudah mapan tetapi mengubah perilaku anak didik pemasyarakatan dari suatu kondisi kepada kondisi yang lebih baik. Upaya ini dilakukan dengan melalui suatu proses pembinaan secara terus menerus berdasarkan proses pemasyarakatan yang sudah relatif mapan.

Pelaksanaan pembinaan yang dilakukan terhadap anak pidana yang berada dalam Lembaga Pemasyarakatan, dalam hal ini disebut sebagai anak didik pemasyarakat tidak selamanya berjalan dengan baik. Lembaga Pemasyarakatan juga dapat mengalami kendala pada saat melaksanakan pembinaan.Dapat dikatakan bahwa kendalakendala tersebut adalah sebagai berikut:

a. Pola dan Tata Letak BangunanPola dan tata letak bangunan sebagaimana diatur dalam keputusan Menteri Kehakiman 
Indonesia Nomor M.01.PL.01.01 Tahun 1985 tanggal 11 April 1985 tentang pola bangunan lembaga pemasyarakatan dan rumah tahanan negara perlu diwujudkan, karena pola dan tata letak bangunan merupakan faktor yang penting guna mendukung pembinaan sesuai dengan tujuan pemasyarakatan.

b. Kualitas dan Kuantitas Petugas Haruslah selalu diusahakan agar kualitas petugas dapat mampu menjawab tantangantantangan dan masalah-masalah yang selalu ada dan muncul di lingkungan lapas disamping penguasaan terhadap tugastugas rutin. Kekurangan dalam kualitas atau jumlah petugas hendaknya dapat diatasi dengan peningkatan kualitas dan pengorganisasian yang rapih agar tidak menjadi ancaman bagi pembinnaan dan keamanan dan ketertiban.

c. Sarana dan Fasilitas Pembinaan Kekurangan sarana dan fasilitas baik dalam jumlah maupun mutu telah menajdii penghambat pembinaan bahkan telah menjadi salah satu penyebab rawannya keamanan atau ketertiban.

d. AnggaranSekalipun dirasakan kurang mencukupi untuk kebutuan seluruh program pembinaan, namun hendaklah diusahakan memanfaatkan anggaran yang tersedia secara berhasil guna dan berdaya guna.

e. Masalah-masalah lain yang berkaitan dengan warga binaan pemasyarakatan.
Jadi Peranan petugas LPKA (Lembaga Pembinaan Khusus Anak) dalam pembinaan anak didik tindak pidana kriminal sudah sesuai dengan peraturan undang-undang SPPA (Sistem Peradilan Pidana Anak), namun masih belum optimal, hal ini dapat dilihat dari kualitas petugas LPKA dalam melaksanakan pembinaan pada anak didik pemasyarakatan petugas menggunakan metode pembinaan perorangan (individual) dari luar diri dan dari dalam diri juga menggunakan metode perkelompok. Metode-metode ini digunakan dalam pembinaan intelektual, keagamaan, dan keterampilan. Saat melaksanakan pembinaan petugas menggunakan tahap-tahap pembinaan seperti tahap awal, tahap lanjutan dan tahap akhir.

Di Dalam hal ini petugas dituntut untuk mampu mengenal masalah-masalah lain yang berkaitan dengan warga binaan pemasyarakatan agar dapat mengatasinya dengan tepat. Umumnya masalah itu berkisar pada :

1). Sikap acuh tak acuh keluarga napi, karena masih ada keluarga napi yang bersangkutan tidak memperhatikan lagi nasip napi tersebut.

2). Kerjasama dengan instansi (badan) tertentu baik yang berkaitan secara langsung maupun tidak langsung masih perluu ditingkatkan juga, karena masih ada diantaranya yang belum terketuk hatinya untuk membina kerjasama 
3). Informasi dan pemberitaanpemberitaan yang tidak seimbang, bahwa cenderung selalu mendiskreditkan lapas sehingga dapatmerusaak citra pemasyarakatan dimata umum.

f. Partisipasi masyarakat. Kurangnya partisipasi masyarakat yang pada kenyataannya masih enggan menerima kembali bekas napi.

\section{PENUTUP}

Faktor Penghambat Lembaga Pembinaan Khusus Anak yaitu Faktor perundangundangan, yaitu belum adanya petunjuk teknis mengenai pembinaan terhadap anak didik pemasyarakatan, faktor kualitas dan kuantitas petugas, namun pihak LPKA sudah menganjurkan dan memberikan saran seluasluasnya kepada para petugas pembina maupun para pegawai lembaga pada umumnya untuk meningkatkan pendidikannya. Faktor sarana dan fasilitas, yaitu masih terbatasnya sarana dan fasilitas yang dibutuhkan petugas dalam pelaksanaan pembinaan serta Faktor masyarakat, yaitu masih adanya sikap negatif masyarakat terhadap mantan anak didik pemasyarakatan yang ttelah dibebaskan dan kembali ke masyarakat.

\section{DAFTAR PUSTAKA}

Mappiare Andi,Pengantar Konseling Dan Psikoterapi, Jakarta: PT RajaGrafindo Persada, 2011.

Marianne H. Mitchell\& Robbert L.Gibson, Bimbingan dan Konseling, Yogyakarta : PUSTAKA PELAJAR,2010.

Mu'awanahElfi, Rifa Hidayah, Bimbingan Konseling Islam di Sekolah Dasar,Jakarta : Bumi Aksara, 2012.

NurulaenYuyun, Lembaga Pemasyarakatan Masalah \& Solusi Perspektif Sosiologi Islam Bandung: Marja, 2012.

Ridwan, Pengantar Statistika Social,Bandung: Alfa Beta, 2009.

Sarwono Sarlito W, Psikologi Remaja Jakarta: PT RajaGrafindo Persada, 2013.

Sudarsono, Kenakalan Remaja, Jakarta: PT Rineka Cipta, 2004.

SukantoSoerjono, Sosiologi Suatu Pengantar, Jakarta: PT RajaGrafindo Persada 2007.

Yulianto, Yul Ernes, Lembaga Pembinaan Khusus Anak Dalam Perspektif Sistem Peradilan Pidana Anak, Jakarta : Badan Penelitian Hukum dan HAM Kementrian Hukum dan HAM Republik Indonesia, 2016. 